\title{
The Effectiveness of Management Model for Multicultural-Based Sociology Training to Enhance Teachers' Professional Competence
}

\author{
Totok Rochana ${ }^{1}$, Maman Rachman $^{2}$, Achmad Slamet $^{3}$, Achmad Rifai ${ }^{4}$ \\ ${ }^{1,2}$ Educational Management, Postgraduate Universitas Negeri Semarang \\ ${ }^{3}$ Faculty of Economics, Universitas Negeri Semarang \\ ${ }^{4}$ Faculty of Educational Sciences, Universitas Negeri Semarang \\ ${ }^{1}$ Corresponding author: toksosant@gmail.com
}

\begin{abstract}
The objectives of this study are: to describe the management model for multicultural-based sociology training to enhance teachers' professional competence; and to describe the effectiveness of management model for multicultural-based sociology training to enhance teachers' professional competence. This study employed qualitative approach to obtain the description and analysis of the findings. The subject of this study is sociology teachers in Semarang. The methods of collecting data used closed-ended questionnaire and openended questionnaire. The data analysis used mean analysis and qualitative descriptive analysis. The findings of this study show that management model for multicultural-based training to enhance teachers' professional competence is designed through three stages, they are: training plan, training implementation, and training evaluation; in addition, management model for multicultural-based training is effectively applied to enhance professional competence. Based on the findings, it is suggested to implement the management model for training on multicultural-based sociology learning.
\end{abstract}

Keywords: Management, Multicultural; Teachers

\section{Introduction}

Sociology subject is one of social sciences subject group which is provided in senior high school level. The purpose of sociology learning is to develop attitude, awareness, and social care in the plural societies life (Permen No.22) The purpose of sociology learning indicates the need for multicultural-based sociology learning. The studies focusing on the multicultural-based learning have been widely conducted.

From the study on the experiences of women of colour in South African doctoral education programs, it can be concluded that the condition of the institution where they study can support in obtaining doctoral degree (Snyder, 2014). The study in an urban school in the United States, with a large number of students and various communities, concluded that there is educational improvement for the minor communities with good academic achievement (Wu, 2014).

In-service training is an effort to enhance competence (Sugiyono, 2002). The importance of in-service training for teachers has been proved through studies. The result of a study concluded that in-service training is effective in improving the training participants' perception (teachers) (Jahangir, 2012). A study result concluded that training by using a module can improve teachers' knowledge competence.

The objectives of this study are: to describe the management model for training on multicultural-based sociology learning to enhance teachers' professional competence; and to describe the effectiveness of management model for training on multicultural-based sociology learning to enhance teachers' professional competence.

\section{Method}

This study employed qualitative approach to obtain the description and analysis of the findings. The subject of this study is sociology teachers in Semarang. The methods of collecting data used closed-ended questionnaire and open-ended questionnaire. The data analysis used mean analysis and qualitative descriptive analysis. The study was conducted in Semarang, Central Java Province.

The subject of this study is sociology teachers of state senior high schools or private senior high schools in Semarang. From 78 sociology teachers in senior high schools in Semarang, 10 teachers were selected as the respondents and informants. The instruments of collecting data used close-ended questionnaire, open-ended questionnaire, observation guide, interview 
guideline, and documentation. The data analysis used descriptive percentage analysis and qualitative descriptive analysis with interactive technique (Milles, 1998).

\section{Result and Discussion}

The management model for training on multicultural-based sociology learning to enhance teachers' professional competence is designed based on the field observation, uses theoretical model, and uses the theory of training management. The theoretical model uses training design and evaluation model is developed by Parker, and it consists of 7 activity steps (the seven-step model), they are: (1) identifying and analyzing training needs; (2) formulating and developing training objectives; (3) designing training curriculum; (4) selecting and developing training method; (5) determining the training evaluation approach; (6) implementing training program; and (7) measuring training outcomes (Kamil, 2015).

Training management model focuses on the training plan function, training implementation function, and training evaluation function. Training plan function includes the analysis of training needs, formulating training goals, and creating the program design and training document. The activities in training plan function are: (1) determining the goal, (2) formulating strategies to achieve the goal, (3) determining necessary resources, and (4) determining the success standard/indicators in achieving the goal (Sule, 2008). In the training plan function, the vital aspect is determining training target. Determining training target is based on the analysis needs. The target can be technical or behavioral (Siagian, 2010)

Training implementation function includes training materials, learning method, as well as pretest and posttest. The activities in this management function are: (1) implementing leadership aspect, guidance aspect, and motivation aspect for workers to work effectively and efficiently in achieving goals; (2) giving tasks and regular explanation about the work; and (3) explaining the applied regulations [9]. In training implementation function, the vital aspect is learning method during the training. To make the training activities run effectively and efficiently, the training activities can use learning principles appropriately (Siagian, 2010)

The training evaluation function includes follow-up and training outcomes implementation. The activities in this management function are: (1) evaluating the success in achieving the goal and target based on the determined indicators; (2) taking clarification step and correction of the irrelevance that may be found; and (3) conducting various alternative problem solving related to the goal achievement [9]. The success of a training can be viewed from two aspects, those are: there is an ability improvement in doing tasks and behavioral changes reflected in the attitude, discipline, and work ethos (Handoko, 2008). Model of Multicultural-based Management to Enhance Teachers' Professional Competence

Model for multicultural-based training management to enhance teachers' professional competence is designed based on the field observation, uses theoretical model, and uses training management theory. Based on the training management theory, training management can enhance the training participants' competence (Sugiyono, 2002). The effectiveness of multiculturalbased training management is measured by using the following indicators: participants' competence, infrastructure competence, training facilities, training plan, training implementation, and training evaluation.

Based on the trials of effectiveness, it obtains the result that the model for multicultural-based training management is effectively applied to enhance teachers' professional competence. The previous study result showed that the model for training on professional competence based on sustainable profession development is proved effective for elementary school teachers training (Hamid, 2013). Another study result shows that short focused training can significantly affect time management in the classroom (Vasiliadou, 2009).

\section{Conclusion}

The study result shows that the model for multicultural-based training management to enhance teachers' professional competence is designed through three steps, they are: training plan, training implementation, and training evaluation; and the model for multicultural-based training management is 
effectively applied to enhance professional competence. Based on the study result, it is suggested that it is necessary to implement the model for training management on multicultural-based sociology learning.

\section{References}

Hamid, A. 2013. "Training Management Model Based on Continuous Prefessional Development for elementary School Teachers". The Journal of Educational Development. 1

http://journal.unnes.ac.id/sju/index.ph p/jed: $1-7$.

Handoko, T. Hani. 2008. Personnel Management \& Human Resources. Yogyakarta: BPFE-YOGYAKARTA.

Ismail, H. N, et al. 2009. "Competency Based Teacher Education (CBTE): A Training Module for Improving Knowledge Competencies for Resource Room Teachers in Jordan". European Journal of Social Sciences, Volume 10, Number 2 (2009):165-178. (Diunduh 27 April 2015).

Jahangir, S.F., Saheen, N., dan Kazmi, S.F. 2012. "In Service Training: A Contributory Factor Influencing Teachers' Performance". International Journal of Academic Research in Progressive Education and Development, January 2012, Vol. 1, No. 1:31-38. (Diunduh 27 April 2015).
Kamil, M. Training Models. Available on https://www.scribd.com/doc/9442322 8/Model-Model-Pelatihan. (Retrieved on 28 April 2015).

Milles, M.B. dan Hubermen, A.M. 1998. Qualitative Data Analysis. Jakarta: UI Press.

Regulation of National Education Minister No 22 of 2006 on Content Standard

Siagian, S. P. 2010. Human Resources Management. Jakarta: Bumi Aksara.

Snyder, C.R. 2014 “A Woman's Place: Women of Colour Navigating Doctoral Education in South Africa". International Journal of Multicultural Education, Vol. 16, No. 2:15-35. (Diunduh 10 Februari 2015).

Sugiyono. 2002. Manajemen DIKLAT. Bandung: Alfabeta.

Sule, E.T., dan Saefullah, K. 2008. Introduction to Management. Jakarta: Kencana Prenada Media Group.

Vasiliadou, O, et al. 2009. "Training Inservice Physical Educators to Improve Class Time Management". International Journal of Sport Science VOLUMEN V - AÑO V Páginas:33-43 ISSN:1885-3137 Nº 17 - Octubre - 2009: 33-41. (Diunduh 20 Desember 2017).Wu, M.H. 2014. "Innovative Education for Diverse Students in a Changing Era: One U.S. Urban School's Alternative Teaching and Learning". International Journal of Multicultural Education, Vol. 16, No. 2:36-55. (Diunduh 10 Februari 2015). 